\title{
Rate constant of the reaction of the peroxyl radical of 1,4-dioxane with $\alpha$-Tocopherol and trolox
}

\author{
(C) Olesya V. Semikasheva, ${ }^{+}$Lucia R. Yakupova, ${ }^{*}$ and Rustam L. Safiullin* \\ Ufa Institute of Chemistry. Ufa Scientific Center. Russian Academy of Sciences. \\ Oktyabrya Ave., 71. Ufa, 450054. Russia. Phonelfax: +7 (347) 2356066. \\ E-mail: olesya.semikashewa@yandex.ru
} \begin{abstract}
Keywords: radical chain oxidation, 1,4-dioxane, inhibition, $\alpha$-tocopherol, trolox, initiation rate, stoichiometric coefficient of inhibition.
\end{abstract}

\begin{abstract}
The study of the properties of water-soluble antioxidants is of practical interest. Research is hindered by the fact that such substances are poorly soluble in substrates, which are most widespread in determining the quantitative characteristics of antioxidants. Usually it is cumene, ethylbenzene, styrene. In this work, we used a method based on a model reaction of the radical chain 1,4-dioxane oxidation. This substrate is the most suitable solvent for evaluating the water-soluble substances antioxidant activity. The inhibitory activity of $\alpha$ tocopherol (vitamin E) and trolox (a water-soluble analogue of $\alpha$-tocopherol) was studied in a model system of radical chain 1,4-dioxane oxidation. Air oxygen served as the oxidizing agent. The experiments were carried out at $333 \mathrm{~K}$. Initiation was carried out with 2,2'-azo-bis-isobutyronitrile. The reaction kinetics was monitored by the rate of oxygen uptake using a manometric setup. In this work to measure the initiation rate, the inhibitors method is used. The standard $\alpha$-tocopherol inhibitor was used for this purpose. $\alpha$-Tocopherol is an effective inhibitor with a known stoichiometric inhibition ratio of two. The method used in our study makes it possible to measure correct the length of the induction period using the kinetics of oxygen absorption. The induction period was determined by graphical and integral methods. The initiation rate was calculated based on the induction period values. The resulting value is in satisfactory agreement with the data based on the literary value of the decay rate constant 2,2'-azo-bis-isobutyronitrile.

The rate constant of the reaction of the 1,4-dioxane peroxyl radical with $\alpha$-tocopherol and trolox $\left(\mathrm{fk}_{7}, \mathrm{~L}\right.$ $\left.\mathrm{mol}^{-1} \mathrm{~s}^{-1}, 333 \mathrm{~K}\right)$ was measured: $(1.6 \pm 0.1) \cdot 10^{6},(1.2 \pm 0.1) \cdot 10^{6}$. The stoichiometric inhibition coefficient for trolox in the system of radical chain 1,4-dioxane oxidation was determined: $\mathrm{f}=2.4 \pm 0.2$.
\end{abstract}

\section{References}

[1] M.E. Alberto, N. Russo, A. Grand, A. Galano. A physicochemical examination of the free radical scavenging activity of Trolox: mechanism, kinetics and influence of the environment. J. Phys. Chem. B. 2013. No.15. P.4642-4650.

[2] L.R. Yakupova, A.V. Ivanova, R.L. Safiullin, A.R. Gimadieva, Yu.N. Chernyshenko, A.G. Mustafin, I.B. Abdrakhmanov. Inhibiting effect of 6-methyluracil derivatives on the free-radical oxidation of 1,4dioxane. Russ. Chem. Bull. 2010. Vol.59. No.3. P.517-521. (russian)

[3] L.R. Yakupova, S.G. Proskurjakov, R.N. Zaripov, Sh.R. Rameev, and R.L. Safiullin. Measurement of the reaction rate proceeding with gas absorption or gas evolution. Butlerov Communications. 2011. Vol.28. No.19. P.71-78. ROI: jbc-02/11-28-19-71

[4] D. Loshadkin, V. Roginsky, E. Pliss. Substituted p-Hydroquinones as a Chain-Breaking Antioxidant During the Oxidation of Styrene. J. Int. Chem. Kin. 2020. Vol.34. No.3. P.162-171.

[5] A.F. Moroni. Über den einfluß des lösungsmittels beim thermischen zerfall des azoisobuttersäuredinitrils. Makromol. Chem. 1967. Vol.105. No.6. P.43-49.

[6] E.T. Denisov. Konstanty skorosti gomoliticheskikh zhidkofaznykh reaktsii (Rate Constants of Homolytic LiquidPhase Reactions), Moscow: Nauka. 1971. P.712. (russian)

[7] L.R. Yakupova, V.R. Khairullina, R.L. Safiullin, A.Ya. Gerchikov, G.R. Baimuratova. Kinetics of the liquid-phase oxidation of 1,4-dioxane in the presence of inhibitors. Kinet. Catal. 2008. Vol.49. No.3. P.366-370. (russian) 
[8] L.R. Jakupova, D.I. Safarova, A.I. Murzagulova, and R.L. Safiullin. Kinetics of the thermal decomposition of 2,2'-azobis(2-amidinopropane)dihydrochloride in an aqueous solution of 1,4-dioxane. Butlerov Communications. 2017. Vol.49. No.3. P.60-66. DOI: 10.37952/ROI-jbc-01/17-49-3-60

[9] L.R. Jakupova, D.I. Safarova, A.I. Murzagulova, and R.L. Safiullin. Free-radical chain oxidation of 1,4dioxane inhibited by 2,3-dihydro-2-thioxo-4 $(1 \mathrm{H})$-pyrimidinone. Butlerov Communications. 2018. Vol.54. No.5. P.68-73. DOI: 10.37952/ROI-jbc-01/18-54-5-68

[10] E.T. Denisov, V.V. Azatyan. Ingibirovanie tsepnykhreaktsii (Inhibition of Chain Reactions). Chernogolovka: Moscow oblast: Ros. Akad. Nauk. 1997. 266p. (russian)

[11] V.F. Tsepalov. In Vitro and In Vivo Studies of Synthetic and Naturally Occurring Antioxidants. Moscow: Nauka. 1992. P.16-26. (russian)

[12] L.B. Kochetova, T.P. Kustova, L.V. Kuritsyn, O.Y. Dicyna. Kinetics and mechanism of acyl transfer reactions. Part 12. Reactivity of aryl amines in amides formation. Butlerov Communications. 2016. Vol.47. No.9. P.95-104. DOI: 10.37952/ROI-jbc-01/16-47-9-95

[13] N.R. Sokolova, E.V. Nikitina, L.B. Kochetova, N.V. Kalinina, T.P. Kustova. Kinetics and mechanism of acyl transfer reactions. Part 2. Kinetics of heterocyclic amines arensulfonylation in aqueous 1,4dioxane Butlerov Communications. 2012. Vol.29. No.1. P.7-14. ROI: jbc-02/12-29-1-7 